\title{
IDENTIFICATION OF POTENTIAL DIESEL OIL-DEGRADING BACTERIA ISOLATED FROM MANADO SEA PORT BASED ON 16S rRNA GENE
}

\author{
Olivia H. Abram ${ }^{1)}$, Trina E. Tallei ${ }^{1}$, \\ Edwin de Queljoe ${ }^{1)}$, Beivy J. Kolondam ${ }^{1)}$ \\ ${ }^{1)}$ Department of Biology, Faculty of Mathematics and Natural Sciences \\ Sam Ratulangi University, Manado \\ e-mail: olive.livz@gmail.com; trinatallei@yahoo.com; \\ edwin_de_queljoe@yahoo.co.id; beivy_jk@yahoo.com
}

\begin{abstract}
Petroleum contamination and its derivate in ecosystem are considered as environmental threat all over the world. Some microorganisms exhibit potential to degrade hydrocarbon in contaminated environments. This study aims at identifying potential diesel oil-degrading bacteria grown on artificial media. Bacteria isolated from Manado Sea port were grown in nutrient agar containing artificial diesel oil plus salt water and diesel oil only, respectively. The growing bacteria were isolated and each of them was grown separately to obtain pure isolate. Three bacterial isolates namely AO2, OA3 and OA4 were identified using 16S rRNA gene as Pseudomonas aeroginosa, Klebsiella oxytoca, and Citrobacter sp, respectively.
\end{abstract}

Keywords: diesel oil, diesel oil-degrading bacteria, Manado Sea Port, 16S rRNA gene

\section{IDENTIFIKASI BAKTERI YANG BERPOTENSI SEBAGAI PENDEGRADASI MINYAK DIESEL DI ISOLASI DARI PELABUHAN LAUT MANADO}

\begin{abstract}
ABSTRAK
Kontaminasi minyak bumi dan turunannya dalam ekosistem dianggap sebagai ancaman lingkungan di seluruh dunia. Beberapa mikroorganisme menunjukkan potensi yang dapat menurunkan hidrokarbon dalam lingkungan yang terkontaminasi. Penelitian ini bertujuan untuk mengidentifikasi bakteri yang berpotensi sebagai pendegradasi minyak yang tumbuh pada media buatan. Bakteri diisolasi dari pelabuhan laut Manado dan ditumbuhkan dalam media NA yang mengandung minyak diesel dengan penambahan air garam buatan dan minyak diesel tanpa air garam buatan. Bakteri yang tumbuh diisolasi dan masing-masing ditanam secara terpisah untuk mendapatkan isolat murni. Tiga isolat bakteri yaitu $\mathrm{AO} 2, \mathrm{AO} 3$ dan $\mathrm{AO} 4$ yang telah diidentifikasi menggunakan 16S rRNA gen secara berturut-turut adalah Pseudomonas aeroginosa, Klebsiella oxytoca, dan Citrobacter sp.
\end{abstract}

Kata kunci: minyak diesel, bakteri pendegradasi minyak diesel, Pelabuhan Laut Manado, gen 16S rRNA

\section{INTRODUCTION}

Petroleum refineries products are needed continously by modern society. However, accident spills of crude oil and its refined product occurs frequently during extraction, transportation, storage, refining, and distribution (Nikolopoulou et al., 2007). This can become serious threat to the environment. Disruption of ecosystem function by hydrocarbon spills among others are respiration and nitrogen cycle (Schafer $e t$ al., 2009). Human, as well as flora and fauna are endangered by the toxicity of the content of oil spill (van Gestel et al., 2001). According to Jusfah (1995), oil contamination does not only poison the living things in all ecosystems, it also disrupts light absorption for photosynthesis of aquatic plants.

Diesel oil is one of most widely used refined petroleum (Yuswono, 2008). 
Continues low-level input of diesel oil accidentally from pipeline, tanker, or storage tank during refuelling creates an accute pollution problem. This spills are rarely noticed and will pose a serious threat to the environment due to accumulation of hydrocarbon contamination.

Marine shorelines serves a sa home to various number of organisms. Any hydrocarbon spills will have a great threats because of damaging capacity to the coastal environtment. Manado sea port is one of the busiest commercial sea port that connects islands of Sangihe, Talaud, and Maluku. This site has a high intensity of daily passangers embarkation due to its location in the central business of Manado city. During embarkation, refuelling, and docking time, diesel oil will be disposed aling with waste water into the sea which then in turn will affect surrounding marine ecosystem. This of course will lead to the pollution load of diesel oil spills around the port is increasingly rising.

There are several ways that can be done to overcome hydrocarbon pollution, namely physical, chemical and biological ways (Udiharto, 1992). The best biological way to mitigaze the polution load is to utilize existing oil degrading microorganisms in the environment. This way does not damage the environment and it is cost-effective. During exposure to hydrocarbon, dynamic composition and functional of marine microbial communities are altered. This favors bacteria that are able to utilize rich carbon source for they have hydrocarbon degradation capacity (Scott et al., 2014). Based on the reasons and facts described above, this study aims at identifying the potential diesel oil-degrading bacteria using partial 16S rRNA gene.

\section{METHODS}

This research was conducted from March 2014 to May 2014. Sampling wastaken place in the waters of the port of Manado. Culture and identification of bacteria were conducted in the laboratory of Biotechnology Laboratory, Department of Biology, Faculty of Mathematics and Natural Sciences, University of Sam Ratulangi.

Samples of bacteria that were suspected to have the potentialto degrade diesel oil were taken from the water of the Port of Manado using a sterilizedbottles.

One milliliter of sea water taken from manado seaport was poured onto NA with diesel oil which did not contain salt and spread evenly. Another $1 \mathrm{~mL}$ of water sample was poured onto NA with diesel oil which contained $0.9 \%$ salt and spread evenly. The media were incubated for $2 \times 24$ hours at $37^{\circ} \mathrm{C}$. Each colony was picked and streak onto the same prepared media and incubated for another $2 \times 24$ hours at $37^{\circ} \mathrm{C}$. The streak plate method produces individual colony on agar. Each pure colony was referred as isolate. Each isolate was transferred to a MacConkey media to start a pure culture. Each isolate grown in MacConkey then was transferred to KIA media for isolate selection.

Extraction of DNA was conducted using protocol provided by the company (InnuPREP DNA Mikro Kit - Analytik Jena $A G)$. Each of pure isolates from KIA media was taken using Oose needle then put into Eppendorf containing $1 \mathrm{~mL}$ of $\mathrm{NB}$ and grown for 6 hours at $37^{\circ} \mathrm{C}$ to reach a an exponential phase. Each tube then was centrifuged at $6000 \mathrm{rpm}$ for 2 minutes and the supernatant was discarded. $300 \mu \mathrm{l}$ of lysis buffer and 25 $\mu l$ protein kinase were added into each tube and vortexed for 5 seconds. Eppendorf tubes then were placed in termoblock at $70^{\circ} \mathrm{C}$ temperature for 15 minutes. To bind the DNA, $200 \mu \mathrm{l}$ of TBS was added into each tube and vortexed. Spin filters were added to receiver tubes. Samples were added into each spin filter and centrifuged at $12.000 \mathrm{rpm}$ for 2 minutes. For washing the DNA, $500 \mu \mathrm{l}$ of HS was added into each tube and centrifuged at $12.000 \mathrm{rpm}$ for 1 minute. $750 \mu \mathrm{l}$ of MS was added then again centrifuged at $12.000 \mathrm{rpm}$ for 1 minute. The washing procedure was repeated twice.

To remove the alcohol, filtrate was removed and spin filter was added to receiver tube and centrifuged at maximum speed for 2 minutes. To elute the DNA, spin filter was added to elution tube and added with 200 of $\mu l$ elution buffer. The tubes were incubated at room temperature for 1 minute and centrifuged at $8000 \mathrm{rpm}$ for 1 minute. The filtrated was kept in freezer until used for DNA amplification process.

DNA amplification was done using Tpersonal-combi Thermo-cycler (Whatman Biometra-Germany). Primers used for PCR 
process were universal namely Bact-F1 forward primer $(10 \mathrm{mM}) \quad$ 5'AGAGTTTGATC (A/C) TGGCTCAG-3' and Uni-B1 reverse primer $(10 \mathrm{mM}) 5^{\prime}-$ GGTTAC (G/C) TTTGTTACGACTT-3' with a total PCR volume of $40 \mathrm{uL}$ with the following reaction mixture (Tabel 1): Ready to Load (RTL) PCR beads, 1 uLof each primer, miliq water and $2 \mathrm{uL}$ of the bacterial DNA.

Table 1. PCR reaction mixture

\begin{tabular}{lcc}
\hline & $\begin{array}{c}\text { Volume } \\
(\mu \mathrm{L})\end{array}$ & $\begin{array}{c}\text { Master mix } \\
(\mu \mathrm{L})\end{array}$ \\
\hline Firepol & 8 & 40 \\
Miliq water & 28 & 140 \\
Primer Bact- & 1 & 5 \\
$\begin{array}{l}\text { F1 } \\
\text { Primer Uni- }\end{array}$ & 1 & 5 \\
B1 & & 10 \\
$\begin{array}{l}\text { DNA } \\
\text { template }\end{array}$ & 2 & \\
\hline Total Vol. & $\mathbf{4 0}$ & $\mathbf{2 0 0}$ \\
\hline
\end{tabular}

Ready-to-load (RTL) PCR tubes with all the ingredients were subjected to the PCR condition as follows: $95^{\circ} \mathrm{C}$ lead heating and DNA predenaturation at $95^{\circ} \mathrm{C}$ for $2 \mathrm{~min}$, followed by 35 cycles of (1) denaturation at $95^{\circ} \mathrm{C}$ for 30 seconds, (2) Primer attachment (annealing) at $50^{\circ} \mathrm{C}$ for 30 seconds, and (3) elongation of DNA at $72^{\circ} \mathrm{C}$ for 90 seconds. Additional polymerization (final extension) was performed at $72^{\circ} \mathrm{C}$ for 1 minute.

Amplified DNA was separated by electrophoresis in 1\% agarose gel. A total of $4 \mathrm{uL}$ of loading dye added into DNA. Electophoresis was done in $0.5 \times$ TBE on 50 volts voltage for 10 minutes and followed by 100 volts for 20 minutes. Afterwards the gel was stained with $1 \mathrm{mg} / \mathrm{mL}$ ethidium bromide for 20 minutes prior to vizualisation. DNA fragments was visualized under UV light from UV-transiluminator. Documentation was done using the Digital Compact BioDoc (Whatman Biometra-Germany).

Amplified DNA fragments were sent to 1Base Malaysia for sequencing procedure. DNA sequencing results were subjected to editing using Geneious to remove unnecessary and unreadable sequences. The edited DNA sequences then were analyzed using BLAST which is available online at NCBI to search similar sequence from available species of bacteria deposited in GenBank.

\section{RESULTS AND DISCUSSIONS}

Bacteria which growed on nutrient agar (NA) with 1-5\% diesel oil (with or without salt) were transferred into MacConkey agar with 3\% diesel oil $+0.9 \%$ salt. MacConkey agar is based on the bile salt-neutral red-lactose agar developed by MacConkey, and it is recommended for detection and isolation of Gram-negative bacteria. During fermentation of lactose, local $\mathrm{pH}$ dropped around the colony causing a color change to neutral red and followed by bile precipitation. Bile salts mixture and crystal violet inhibited Gram-positive cocci, thus serves as selective agents that only allows Gram-negative bacteria to grow (Figure 1). The bacteria growed on this medium was picked individually and grown on KIA slant media.

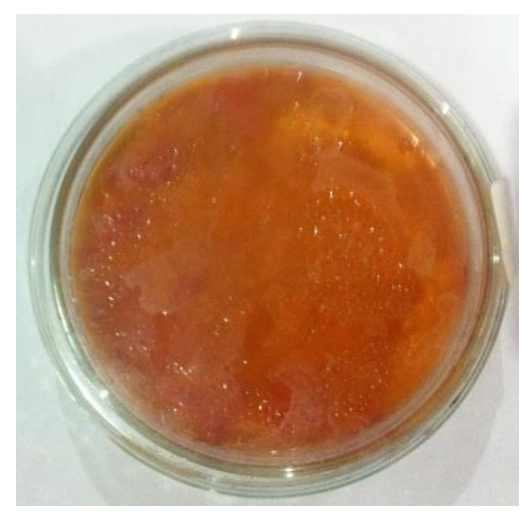

Figure 1. Bacterial growth on MacConkey medium with $3 \%$ diesel oil $+0.9 \%$ salt

Kligler iron agar (KIA) was used to differentiate microorganism on the basis of lactose and glucose fermentation (with or without gas production) and hydrogen sulfide production.

Isolate $\mathrm{AO} 2$ is a nonfermenter organism therefore it is not capable of using glucose or lactose. This organism only uses solely amino acids/proteins. This is indicated by red color of the slant, and the color of the butt remains unchanged (Figure 2A). 


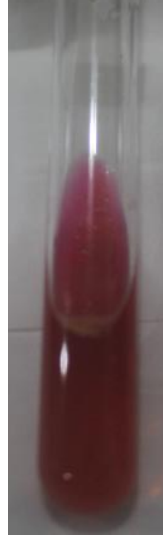

A

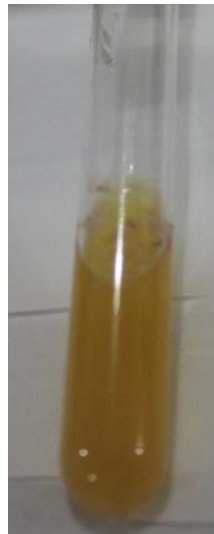

B
C

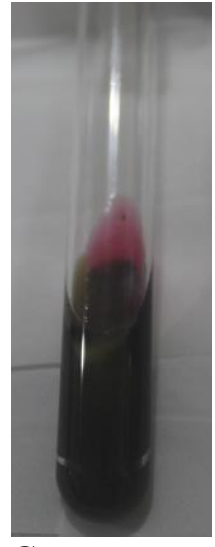

Figure 2. Reactions of microorganisms on KIA slant media containing. (A) Isolate $\mathrm{AO} 2$, (B) Isolate $\mathrm{AO} 3,(\mathrm{C})$ Isolate $\mathrm{AO} 4$

Isolate AO3 is a glucose and lactose fermenter. Therefore caused the reaction to become acid over acid (A/A), which indicated that glucose and lactose have been metabolized.This bacterium quickly metabolized glucose producing an acid slant and an acid butt in a few hours (Figure 2B).

Isolate $\mathrm{AO} 4$ is a glucose fermenter, thus the tube reaction was alkaline over acid (K/A) signifying that only glucose is metabolized. This bacteria quickly metabolized glucose, initially produced an acid slant and acid butt (A/A) in few hours. After further incubation (18 hours) the glucose was consumed. Since the bacteria cannot use lactose, the amino acids were utilized as an energy source aerobically in the slant. Utilization of amino acids released ammonia $\left(\mathrm{NH}_{3}\right)$ thus increasing the $\mathrm{pH}$, which turned yellow color into red. The butt remained acidic. It also produced $\mathrm{H}_{2} \mathrm{~S}$ (black color) (Figure 2C).

Figure 3 shows the amplified DNA visualized under UV light. The picture clearly shows that amplified DNA fragment of isolate $\mathrm{AO} 2, \mathrm{OA} 3$, and $\mathrm{OA} 4$ can be proceeded for sequencing due to its band quality.

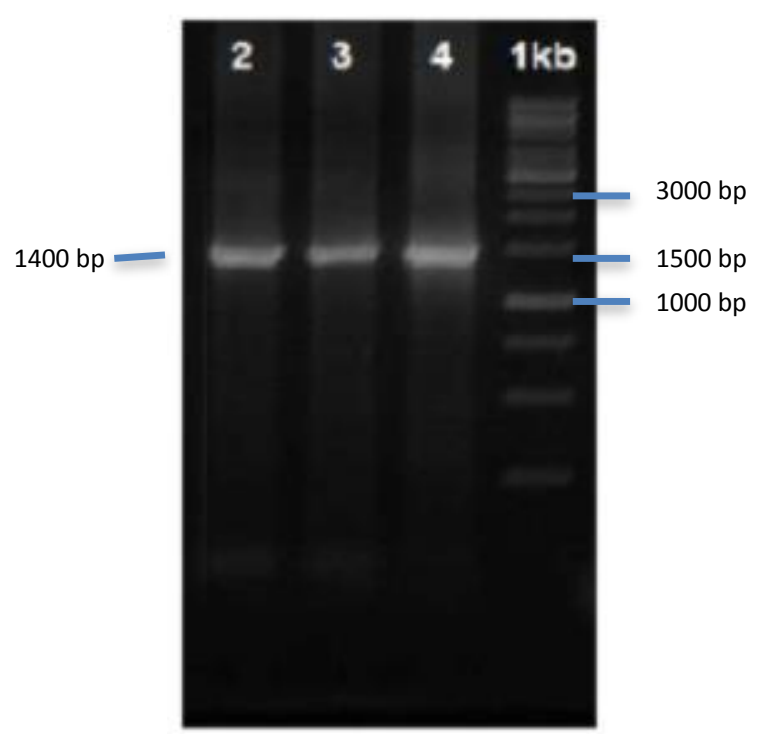

Figure 3. PCR analysis of 16S rDNA fragments on $1 \%$ agarose gel DNA. Primers were able to amplify $1.4 \mathrm{~kb}$ fragment of $16 \mathrm{~S}$ rDNA. Lane 2: isolate AO2; Lane 3: isolate AO3; Lane 4: isolate AO4. $1 \mathrm{~kb}$ : ExactMark $1 \mathrm{~kb}$ ladder.

Sequence of the three PCR products $(\mathrm{AO} 2, \mathrm{AO} 3, \mathrm{AO} 4)$ obtained by applying primers BactF1 and UniB1 yielded only approximately 400 bases. This is due to poor quality of DNA amplification products. By performing a BLAST search within the GenBank database, the most similar sequences were identified. Isolate $\mathrm{AO} 2$ is highly similar (98\%) with Pseudomonas aeruginasa strain TH-61 found in activated sludge of the biochemical pool of Dagang oilfield wastewater treatment plant in Beijing, China. Isolate AO3 is highly similar (98\%) with Klebsiella oxytoca strain A2 isolated from oil-polluted soil in Tehran Iran. Isolate AO4 is highly similar (98\%) with Citrobacter sp. isolated from oil-polluted soil in Tianjin China. According Rajasa (2004), if the percentage of homology ismore than $97 \%$ then it is the same species, between $93 \%$ and $97 \%$ belongs to the same genus with different species, and if less than $93 \%$ then there is the chance that it is a new species.

Mukherjee et al. (2010) reported that Pseudomonas aeruginosa isolated from crude oil at oil field in Assam, India, was capable to utilize hexadecane, benzene, or toluene as a sole carbon source aerobically. This bacterium produced extra cellular lipase that plays an essential role in hydrocarbon degradation, thus it is potential for 
bioremediation of various hydrocarboncontaminated environments.

Zang et al. (2005) assessed crude oil biodigredation potential of Pseudomonas aeruginosa. They found that this bacterium produced $15.4 \mathrm{~g} / \mathrm{L}$ rhamnolipids when cultured in a basal mineral medium with glycerol as a sole carbon source. Pseudomonas aeruginosa is a gamma proteobacterium which is known to produce rhamnolipid and able to utilize and grow in high concentrations of crude oil. Rhamnolipid itself has been reported capable of stimulating biodegradation of hydrocarbons (Patel et al. 2014).Udochukwu et al. (2014) stated that $P$. aeroginosa is the predominant species in petroleum degradation and always found in every oil pollution site analyzed.

Chamkha et al. (2011) successfully isolated Klebsiella oxytoca strain BSC5 from an off shore oil field in Tunisia. Phylogenetic analysis of 16S rRNA gene sequence revealed that it has $99 \%$ sequence similiry with other Klebsiella oxytoca. This strain was capable of degrading a wide range of aliphatic hydrocarbons from $\mathrm{C} 13$ to $\mathrm{C} 30$. Another finding showed that $K$. oxycota isolated from crude petroleum oil samples in Saudi Arabia was able to utilize four different PAHs, namely phenanthrene, fluoranthene, pyrene, and benzene. This bacterium utilized almost $83 \%$ of benzene after $48 \mathrm{hrs}$ of shaking if supplemented with nitrogen source (Mohamed et al., 2012).

According to Singh and Lin (2008), their isolate Citrobacter freundii $\left(\mathrm{MRC}_{3}\right)$ was able to degrade $86.94 \%$ diesel oil in two weeks. The bacterium was isolated from diesel-contaminated soil samples collected from a transport company in Kwazulu-Natal, South Africa.

According to $\mathrm{Wu}$ et al. (2013), to effeiciently degrade polycyclic aromatic hydrocarbons $(\mathrm{PAH})$ in oil-contaminated soil a consortium of many different bacterial species is required. They obtained six PAHdegrading microbial consortia from oilcontaminated soils, and Pseudomonas aeruginosa, Klebsiella oxycota, and Citrobacter sp. are included. Erdoğan et al. (2011) found 33 strains of bacteria capable of degrading hydrocarbon. Those bacteria isolated from contaminated soil in Adana, Batman, and Adiyaman, Turkey among others were Pseudomonas aeruginosa, Klebsiella pneumonia, Citrobacter koseri, and Citrobacter amalonaticus.

In order to achieve optimum degradation of hydrocarbon, an immobilized microbial consortium is suggested here, which comprises of a synergistic mixture of bacterial strains. Bacterial isolates found in this research can be used for finding a microbial consortium formulation, preferably using a biodegradable and economically cheaper immobilization support such as coconut fiber.

\section{CONCLUSION}

Bacterial isolates consortium that have the potential to degrade diesel oil has been isolated from Manado seaport. Three bacterial isolates namelyAO2, $\mathrm{AO} 3$ and $\mathrm{AO} 4$ were identified using partial 16S rRNA gene as Pseudomonas aeroginosa, Klebsiella oxytoca, and Citrobacter sp, respectively.

\section{REFERENCES}

Bona, C., I.M. de Rezende, G. de Oliveira Santos, and L.A. de Souza. 2011. Effect of soil contaminated by diesel oil on the germination of seeds andthe growth of Schinustere binthifolius Raddi (Anacardiaceae) Seedlings. J. Braz. arch. biol. technol.Vol.54, n. 6: pp.1379-1387,

Chamkha, M., Y. Trabelsi, S. Mnif and S. Sayadi. 2011. Isolation and characterization of Klebsiella oxytoca strain degrading crude oil from a Tunisian off-shore oil field. J Basic Microbiol.(6):580-9. doi: 10.1002/jobm.201100073.

Clark, R.B. 2003.Marine Pollution. Oxfford University Press, New York.

Crawford, R.L. dan D.L. Crawford. 1996. Bioremediation principles and applications. Cambridge University Press, Cambridge.

Dwinanto, R. 2011. Identifikasi Isolat Bakteri dari Pantai Papuma Jember Berdasarkan Sekuen DNA Pengkode 16S rRNA [Skripsi]. Jurusan Biologi FMIPA Universitas Jember, Jember.

Erdoğan, E.E., F. Sahin, and A. Karaca. 2011. Determination of petroleumdegrading bacteria isolated from crude 
oil-contaminated soil in Turkey. African Journal of Biotechnology.http://www.academicjo urnals.org/AJB [diaksestanggal 20 Oktober 2014].

Jusfah, J. 1995. Peranan Mikroorganisme Dalam Pengelolaan Limbah Untuk Mengatasi Pencemaran Lingkungan. Pidato Pengukuhan Sebagai Guru Besar Tetap Dalam Ilmu Biologi FMIPA Universitas Andalas, Padang.

Joung, K.B., and J.C. Cote. 2001. Phylogenetic Analysis of Bacillus thuringiensis Serovars Based on 16S rRNA Gene Restriction Fragment Length Polymorphisms. Journal of Applied Microbiology.90:115-122.

Lindquist, J. 2014. Bacteriology 102: Kligler Iron Agar Reactions. http://www.splammo.net/bact102/102k iapage.html [diaksestanggal 20 Oktober 2014]

Mohamed, E.A.H., N.M.H. Yousef, and A.G. Farag. 2012. Isolation and molecular identification of polyaromatic hydrocarbons-utilizing bacteria from crude petroleum oil samples. African Journal of Microbiology Research.6(49):7479-7484. Doi:10.5897/AJMR12.810

Mukherjee, S., N.K. Bardolui, S. Karim, V.V. Patnaik, R.K. Nandy, and P.K. Bag. 2010. Isolation and characterization of a monoaromatic hydrocarbondegrading bacterium, Pseudomonas aeruginosa from crude oil. J. Environ. Scie. Health A. Tox Hazard Subst Environ Eng. 45(9):1048-1053 doi: 10.1080/10934529.2010.486328

Mukhtasor.2007. Pencemaran Pesisir dan Laut. Edisi I. Pradnya Paramita, Jakarta.

Munir, E. 2006. Pemanfaatan Mikroba dalam Bioremediasi: Suatu Teknologi Alternatif untuk Pelestarian Lingkungan. Pidato Pengukuhan Jabatan Guru Besar dan Tetap Bidang Mikrobiologi dalam Rapat Terbuka. FMIPA USU, Medan.

Nikolopoulou, M., N. Pasadakis, N. Kalogerakis. 2007. Enhanced bioremediation of crude oil utilizing lipophilic fertilizers. $J$. Desalination.211:286-295.
Nugroho, A. 2006. Bioremediasi Hidrokarbon Minyak Bumi. Graha Ilmu, Yogyakarta.

Pangastuti, A. 2006. Definisi Spesies Prokaryota Berdasarkan Urutan Basa Gen Penyandi 16s rRNA dan Gen Penyandi Protein.J. Biodiversitas.7(3): 292-296

Patel, P.A., V.V. Kothari, C.R. Kothari, P.R. Faldu, K.K. Domadia, C.M. Rawal, H.D. Bhimani, N.R. Parmar, N.M. Nathani, P.G. Koringa, C.G. Joshi and R.K. Kothari. 2014. Sequence of petroleum hydrocarbon-degrading Pseudomonas aeruginosa Strain PK6, isolated from the Saurashtra region of Gujarat, India. Genome Announc.2(1): $1 \quad$ e00002-14doi: 10.1128/genomeA.00002-14

Radjasa, O.K. 2004. Deep-Sea Bacteria and Their Biotechnological Potentials. J. Coast Dev.7:109-118.

Schafer A.N., I. Snape, and S.D. Siciliano. 2009. Influence of Liquid Water and Soil Temperature on Petroleum Hydrocarbon Toxicity in Antarctic Soil. J. Environmental Toxicology and Chemistry.28:1409-1415

Singh, C. and J. Lin. 2008. Isolation and characterization of diesel oil-degrading indigenous microorganisms in Kwazulu-Natal, South Africa. African Journal of Biotechnology 7(12):19271932.

Singh, S., P. Goswami, R. Sing., and K.J. Heller. 2009. Aplication of Molecular Identification Tools for Lactobacillus, with a Focus on Discrimination between Closely Related Species. A Review. J. LWT Food Science and Technology.42:448-457.

Sukoco dan Zainal Arifin. 2008. Teknologi Motor Diesel. Alfabeta, Bandung.

Supraptono. 2004. Bahan Bakar dan Pelumas. Buku Ajar. Semarang: Jurusan Teknik Mesin UNNES, Semarang.

Udiharto.1992. Aktivitas Mikroba dalam Degradasi Crude Oil. Diskusi Ilmiah VII Hasil Penelitian PPPTMGB "LEMIGAS", Jakarta.

Udiharto, M., S.A. Rahayu, A. Haris dan Zulkifliani. 1995. Peran bakteri dalam degradasi minyak dan pemanfaatannya 
dalam penanggulangan minyak bumi buangan. Proceedings Diskusi Ilmiah VIII PPTMGB. Lemigas, Jakarta.

Udochukwu, U., E.M. Omoghie, C.C. Chikezie, and O.C. Udinyewe. 2014. The role of bacteria in the mineralization of diesel-base engine oil. International Journal of Pharmaceutical Science Invention.3(7):2319 - 6718

Van Gestel, C.A.M., J.J. van der Waarde, J.G.M. Derksen, E.E. van der Hoek, M.F.X.W. Veul, S. Bouwens, B. Rusch, R. Kronenburg, and G.N.M. Stokman. 2001. The use of acute and chronic bioassays to determine the ecological risk and bioremediation efficiency of oil-polluted soils. $J$. Environmental Toxicology and Chemistry.20:1438-1449.

Wang, L.K., J.H. Tay., S.T.L. Tay., Y.T. Hung. 2010. Environmental Bioengineering.Volume 11. Humana Press.

Widyati, E. 2008. Peranan Mikroba Tanah pada Kegiatan Rehabilitasi Lahan Bekas Tambang.Info Hutan.pp.5(2):151-160.

Wu, M., L. Chen, Y. Tian, Y. Ding, and W.A. Dick. 2013. Degradation of polycyclic aromatic hydrocarbons by microbial consortia enriched from three soils using two different culture media. J. Environmental Pollution 178:152-158.

Yoeswono. 2008."Pemanfaatan Abu Tan dan Kosong Kelapa Sawit sebagai Katalis Basa pada Reaksi Transesterifikasi dalam Pembuatan Biodiesel," PKMI08-1. Jurusan Kimia, Fakultas FMIPA, UGM, Yogyakarta.

Zajic., J.E., Cooper, D.G., Jack, T.R., N. Kosaric, and J. Akit. 1983. Biosurfactant in Bitumen Separation From Tar Sand In :Microbial Enhanced Oil Recovery. Ed. Oklahoma, USA : Penn Well Publishing.

Zhang, Y., and R.M. Miller. 1995. Effect of rhamnolipid (biosurfactant) structure on solubilization and biodegradation of n-alkanes. J. Appl. Environ. Microbiol.61: 2247-2251.

Zhang, G-L., Y-T. Wu, X-P. Qian and Q. Meng. 2005. Biodegradation of crude oil by Pseudomonas aeruginosa in the presence of rhamnolipids. J. Zhejiang Univ Sci B.6(8): 725730.doi: 10.1631/jzus.2005.B0725 